Advance Journal of Food Science and Technology 18(1): 1-8, 2020

DOI:10.19026/ajfst.18.6040

ISSN: 2042-4868; e-ISSN: 2042-4876

(C) 2020 Maxwell Scientific Publication Corp.

Submitted: April 27, 2019

Accepted: July 12, 2019

Published: April 25, 2020

\title{
Research Article Anti-Quorum Sensing Activity of Argentinean Honey and Effect of pH on Main Flavonoids
}

\author{
${ }^{1,2}$ Cristina S. Chiappe, ${ }^{1}$ Miriam O. Iurlina and ${ }^{1}$ Amelia I. Saiz \\ ${ }^{1}$ Grupo de Investigación Bromatología, Departamento de Química, Facultad de Ciencias Exactas y \\ Naturales, Universidad Nacional de Mar del Plata (UNMDP), Funes 3350, C.P. 7600, \\ Mar del Plata, Buenos Aires, \\ ${ }^{2}$ Consejo Nacional de Investigaciones Científicas y Técnicas (CONICET), Mar del Plata, Argentina
}

\begin{abstract}
In this study, the anti-QS activity of regional floral honey from the southeast region of Argentina was investigated using the bacterial model Chromobacterium violaceum. In addition, the anti-QS activity of quercetin, myricetin and luteolin was evaluated in an acidic medium. Two of the tested honey samples had the capacity to exert a notable anti-QS effect on C. violaceum. The effect of quercetin on the anti-QS activity at $\mathrm{pH} 5.8$ was higher than myricetin and luteolin. The results obtained from the identification of quercetin, myricetin and luteolin of the honey extracts by High-Performance Liquid Chromatography (HPLC) showed that quercetin was the main flavonoid followed by myricetin and luteolin. It was observed that honey with high values of quercetin and high value of free acidity, exerted a greater effect on the inhibition of QS. Thus, we can conclude that an umbral value of $\mathrm{pH}$ seems to be necessary to increase the anti-QS activity of quercetin.
\end{abstract}

Keywords: Acidity, anti-QS activity, cell-to-cell communication, Chromobacterium violaceum, floral honey, main flavonoids

\section{INTRODUCTION}

The current quest for new antimicrobials is nowadays aimed at discovering non-toxic inhibitors of Quorum Sensing (QS) from natural sources which can be used to avoid the growth of bacteria. QS has been shown to modulate the expression of genes involved in processes related to survival, virulence and pathogenicity of many spoilage bacteria. Quorum Sensing is a signal system of bacteria to determine their population density through the synthesis, release and capture of autoinducers (Bassler, 1999; Brackman et al., 2009). This cell to cell signaling system is mediated by chemical signal molecules. Gram-negative bacteria use a QS system mediated by diffusible molecules of N-Acyl-Homoserine Lactone (AHLs) (Gram et al., 2002). In the past few years, studies have demonstrated that many plants produce anti-QS substances. Vasavi et al. (2014) showed anti-QS activity Centella asiatica against Chromobacterium violaceum and Pseudomonas aeruginosa. Vattem et al. (2007) demonstrated that various phytochemical extracts which inhibited QS also inhibited swarming of pathogenic bacteria, known to be modulated by QS. Traditionally honey has been considered to have antibacterial activity related to factors such as $\mathrm{pH}$, sugar contents, hydroxide peroxide $\left(\mathrm{H}_{2} \mathrm{O}_{2}\right)$ and the presence of phytochemicals, mainly phenolic compounds including phenolic acid, flavonoids, etc. (Mavric et al., 2008). Truchado et al. (2009) had reported that phenolic compounds of monofloral honey contributed to the non-peroxide anti-QS activity. Indeed, the action of flavonoids like quercetin, naringenin, etc., on the modulation of bacterial QS, biofilm generation and virulence factor has been reported (Vikram et al., 2010). Flavonoids like myricetin, kaempferol and quercetin can affect the expression of specific genes and then decrease the synthesis of QS molecules (Vandeputte et al., 2011). Therefore, the inhibition of QS of spoilage potential microorganism by honey is considered as a mechanism to avoid spoilage. Argentina is the third largest producer of honey and Buenos Aires is the largest honey-producing province in Argentina accounting for more than $50 \%$ of Argentina's honey production. Even though there are studies focused on antimicrobial activity of Argentinean honey (Fangio et al., 2010; Isla et al., 2011), there is no information about the anti-QS activity of regional honeys. In addition, the relationship between acidity and the antiQS activity of major flavonoids was studied.

\footnotetext{
Corresponding Author: Cristina Susana Chiappe, Grupo de Investigación Bromatología, Departamento de Química, Facultad de Ciencias Exactas y Naturales, Universidad Nacional de Mar del Plata (UNMDP), Funes 3350, C.P. 7600, Mar del Plata, Buenos Aires, Argentina, Tel.: (0223)155-203481

This work is licensed under a Creative Commons Attribution 4.0 International License (URL: http://creativecommons.org/licenses/by/4.0/).
} 
Adv. J. Food Sci. Technol., 18(1): 1-8, 2020

Table 1: Floral origin, date of harvest and color of honey samples

\begin{tabular}{llll}
\hline Honey sample & Month/Year of harvest & Type of honey, main plant sources & Color $(\mathrm{mm}$ Pfund) \\
\hline HC1 & November 2015 & Multifloral (eucalyptus, llanten, clover, thistle) & Extra white $\left(17^{\mathrm{b}}\right)$ \\
HC2 & November 2015 & Multifloral (eucalyptus, thistle) & Extra clear amber $\left(38.2^{\mathrm{c}}\right)$ \\
HC3 & January 2015 & Multifloral (eucalyptus, thistle) & White $\left(32.2^{\mathrm{c}}\right)$ \\
HC4 & March 2015 & Multifloral (clover, thistle, dandelion) & Water white $\left(1^{\mathrm{a}}\right)$ \\
HC5 & December 2015 & Multifloral (clover, thistle) & Clear amber $\left(53.4^{\mathrm{d}}\right)$ \\
\hline a,b,c,d. The subscripts letters along the column indicate significant difference $(\mathrm{p}<0.05)$ &
\end{tabular}

a,b,c,d: The subscripts letters along the column indicate significant difference $(\mathrm{p}<0.05)$

\section{MATERIALS AND METHODS}

Honey samples: Five floral honey samples collected during 2015 flowering season were used. Honey samples came from individual apiaries located at the southeast of Buenos Aires province (38 $8^{\circ}$ ' S, $57^{\circ} 33^{\prime}$ O) in Argentina. Samples were stored at $4^{\circ} \mathrm{C}$ in the dark until their use. Details of the honey samples used in the assays are described in Table 1 .

Honey physicochemical parameters: Moisture was determined with an Abbe refractometer. Liquid honey was placed directly on the prism and solid honey was first dissolved in a water bath $\left(\leq 40^{\circ} \mathrm{C}\right)$. Readings were made at room temperature. Moisture content values were obtained from Chataway's Table (Bianchi, 1984). Free acidity was expressed as milliequivalents of $\mathrm{NaOH} / \mathrm{Kg}$ of honey and was determined by acid-base titration. Honey samples (10 g each) were diluted in 75 $\mathrm{mL}$ of $\mathrm{CO}_{2}$-free distilled water and titrated with a solution of $\mathrm{NaOH}(0.1 \mathrm{~N})$ stirring constantly until reaching a $\mathrm{pH}$ of 8.5 using a $\mathrm{pH}$-meter (HANNA model HI 9321) (Bianchi, 1984). The $\mathrm{pH}$ of honey samples was determined according to Iurlina and Fritz (2005).

The color was measured by the spectrophotometric method (Bath and Singh, 1999) with some modifications. Five grams of honey was dissolved in distilled water and filtered and the absorbance was read at $635 \mathrm{~nm}$ using an UV-vis Scanning spectrophotometer model Agilent 8453. Measures were correlated with Pfund's value scale (Ferreira et al., 2009).

Total phenolic content was determined using the Folin-Ciocalteu method (Singleton et al., 1999) with some modifications. $100 \mathrm{~mL}$ of the honey solution was mixed with the Folin-Ciocalteu reagent $(2 \mathrm{~N})(100 \mu \mathrm{L})$, vortexed and after $5 \mathrm{~min}$ of repose, $\mathrm{Na}_{2} \mathrm{CO}_{3}(300 \mu \mathrm{L})$ was added and incubated in a water bath $\left(40^{\circ} \mathrm{C}\right)$ for 30 min. Measurements were made at $765 \mathrm{~nm}$. Results were obtained by extrapolation using a calibration curve ( 0 to $0.8 \mathrm{mg} / \mathrm{mL}$ ) and expressed as milligrams of gallic acid equivalents in $100 \mathrm{~g}$ of honey (mg GAE/100 g).

Standards: Flavonoid aglycones used were quercetin dehydrate (minimum 98\%), luteolin (99\%) from Sigma (USA) and myricetin ( $\geq 95 \%$ ) from Fluka (Switzerland). A stock solution was prepared in methanol HPLC grade $(1 \mathrm{mg} / \mathrm{mL})$ and stored at $-20^{\circ} \mathrm{C}$.

Flavonoid extraction: The flavonoid extraction was made using an adsorption resin Amberlite XAD-4 (Fluka Chemie; pore size $9 \mathrm{~nm}$, particle size 0.3-1.2 $\mathrm{mm}$ ) (Iurlina et al., 2009). For each honey sample, $50 \mathrm{~g}$ was dissolved with five parts of water $\mathrm{pH} 2$ (adjusted with concentrated $\mathrm{HCl}$ ), filtered and then put onto the resin column $(40 \times 1.2 \mathrm{~cm})$. The column was washed with acid water $\mathrm{pH} 2(100 \mathrm{~mL})$ and subsequently washed twice with water $\mathrm{pH} 7(200 \mathrm{~mL})$. The whole phenolic fraction was then eluted with methanol (100 $\mathrm{mL})$ and concentrated under reduced pressure $\left(40^{\circ} \mathrm{C}\right)$ using a rotary evaporator model Büchi 461. The phenolic compounds were extracted with ethyl ether (5 $\mathrm{mL} \times 3)$ and the solvent was removed by flushing with nitrogen. The dried residue was redissolved in $1 \mathrm{~mL}$ of methanol (HPLC grade), membrane filtered $(0.2 \mu \mathrm{m})$ and analyzed by HPLC. Extracts were stored at $-20^{\circ} \mathrm{C}$ until their use.

HPLC analysis of honey flavonoids: A SHIMADZU model Prominence Analytical HPLC (diode array detector) system was used. The analysis of flavonoid extracts was carried out using a reversed-phase column end-capped $(150 \times 4.60 \mathrm{~mm})$ Gemini $3 \mu \mathrm{m} \mathrm{C} 18110 \AA ̊$ (Phenomenex, USA). Elution was performed at a solvent flow rate of $1 \mathrm{~mL} / \mathrm{min}$ using a gradient of methanol (solvent A) and water:formic acid, 19:1 (v/v) (solvent B) (Iurlina et al., 2009). The chromatograms were recorded at $340 \mathrm{~nm}$. The identification of chromatographic peaks was based on the retention time compared with standard solutions, quercetin (11.5 min), myricetin $(24.8 \mathrm{~min})$ and luteolin $(25.5 \mathrm{~min})$. The concentration of quercetin, myricetin and luteolin were calculated using the external standard method based on peak area. The calibration curves of each flavonoid were prepared from each stock solution diluted with methanol to obtain working solutions from 0.01 to 0.1 $\mu \mathrm{g} / \mu \mathrm{L}$. The concentrations were correlated with the measured area.

Strain and culture conditions: $C$. violaceum wild-type strain ATCC (American Type Culture Collection) 12472 (Malbrán Institute, Argentina) was used for the anti-QS assays. Bacterial strain was cultured aerobically in Luria-Bertani (LB) broth supplemented with $1.5 \%(\mathrm{w} / \mathrm{v})$ of sodium chloride $(\mathrm{NaCl})$. Cell counts were made on LB agar (1.2\%) supplemented with $1.5 \%$ $(\mathrm{w} / \mathrm{v})$ of $\mathrm{NaCl}$ and incubated at $30^{\circ} \mathrm{C}$ for $24 \mathrm{~h}$.

Agar-well diffusion assay: The agar-well diffusion assay was performed to determine the pigment inhibition of honey samples to obtain a qualitative 
Adv. J. Food Sci. Technol., 18(1): 1-8, 2020

Table 2: Physicochemical characterization of honey

\begin{tabular}{|c|c|c|c|c|}
\hline Honey sample & Moisture (\%) & $\mathrm{pH}$ & $\begin{array}{l}\text { Free acidity } \\
\text { (meq } \mathrm{NaOH} / \mathrm{Kg} \text { of honey) }\end{array}$ & $\begin{array}{l}\text { Total phenolic compounds } \\
\text { (GAE*/100 g of honey) }\end{array}$ \\
\hline$\overline{\mathrm{HC}} 1$ & $20 \pm 0.81^{\mathrm{a}}$ & $3.85 \pm 0.07^{\mathrm{a}}$ & $32.19 \pm 0.27^{b, c}$ & $14.42 \pm 0.1^{\mathrm{c}}$ \\
\hline $\mathrm{HC} 2$ & $17 \pm 0.82^{\mathrm{a}}$ & $3.92 \pm 0.04^{\mathrm{a}}$ & $33.06 \pm 0.04^{\mathrm{b}, \mathrm{c}}$ & $8.92 \pm 0.06^{\mathrm{b}}$ \\
\hline $\mathrm{HC} 3$ & $17.8 \pm 0.61^{\mathrm{a}}$ & $4.03 \pm 0.02^{\mathrm{a}}$ & $24.36 \pm 0.4^{b}$ & $7.61 \pm 0.04^{\mathrm{a}, \mathrm{b}}$ \\
\hline $\mathrm{HC} 4$ & $17.6 \pm 0.83^{\mathrm{a}}$ & $4.44 \pm 0.1^{\mathrm{a}}$ & $16.53 \pm 0.06^{\mathrm{a}}$ & $7.36 \pm 0.08^{\mathrm{a}}$ \\
\hline HC5 & $16.8 \pm 0.62^{\mathrm{a}}$ & $4.5 \pm 0.1^{\mathrm{a}}$ & $17.4 \pm 0.32^{\mathrm{a}}$ & $10.73 \pm 0.17^{\mathrm{b}}$ \\
\hline
\end{tabular}

screening. LB agar (1.2\%) plates were made by adding approximately $10^{5} \mathrm{CFU} / \mathrm{mL}$ of an overnight culture of C. violaceum. Wells were filled with $20 \mu \mathrm{L}$ of each honey concentration $(1,5,10,20,30,40$ and $66 \% \mathrm{w} / \mathrm{v}$, respectively). DMSO was used as negative control and $\mathrm{H}_{2} \mathrm{O}_{2}$ as positive inhibitory control. Plates were incubated for $24 \mathrm{~h}$ at $30^{\circ} \mathrm{C}$ to corroborate the inhibition of pigment production around the well. Concentrations of honey with bactericidal effect were not considered for subsequent assays. The experiment was carried out three times and was three replicates per honey concentration.

QS Inhibition assay: Flask incubation assays were performed to quantify the pigment production of $C$. violaceum against honey samples. Bacteria $\left(10^{5}\right.$ $\mathrm{CFU} / \mathrm{mL}$ ) was grown in $\mathrm{LB}+$ broth supplemented with $1,2,3,4,5,8$ and $10 \%(\mathrm{w} / \mathrm{v})$ of honey and incubated at $30^{\circ} \mathrm{C}$ for $24 \mathrm{~h}$ in aerobic conditions. The quantification of violacein was carried out according to Choo et al. (2006) with some modifications. Two milliliters of the culture was centrifuged at $9000 \mathrm{rpm}$ for $15 \mathrm{~min}$ to precipitate the insoluble violacein. Then the pellet was solubilized in Dimethyl sulfoxide $(2 \mathrm{~mL})$, vortexed to homogenize violacein and centrifuged at $9000 \mathrm{rpm}$ for $15 \mathrm{~min}$ to remove cells. The absorbance of violacein supernatant was measured at $585 \mathrm{~nm}$. The anti-QS effect was determined by measuring violacein and cell counts after $24 \mathrm{~h}$ of incubation.

Major flavonoid anti-QS activity: The anti-QS activity of myricetin, quercetin and luteolin was evaluated at $\mathrm{pH} 5.8$ and $6.7(\mathrm{pH}<5$ inhibits $C$. violaceum growth). The culture $\mathrm{pH}$ was adjusted to 5.8 with buffer $0.07 \mathrm{M}\left(\mathrm{KH}_{2} \mathrm{PO}_{4} / \mathrm{K}_{2} \mathrm{HPO}_{4}\right)$. A stock solution of each flavonoid was prepared in methanol (500 $\mu \mathrm{g} / \mathrm{mL}$ ). One hundred milliliters of LB broth was inoculated with $10^{5} \mathrm{CFU} / \mathrm{mL}$ of an overnight culture of C. violaceum and spiked with different concentrations of individual flavonoids $11,22,59,110,185$ and 370 $\mu \mathrm{g}$, these flavonoid concentrations are usually found in floral honey from Buenos Aires province (Iurlina et al., 2009). The control sample consisted of incubating the microorganism in LB broth without adding the bioactive. Flasks were incubated at $30^{\circ} \mathrm{C}$ for $24 \mathrm{~h}$.

Statistical analysis: Analyses were carried out in triplicate and the data were expressed as means \pm standard deviations (SD), which were calculated using
Excel (Microsoft Office, Version 2010). Statistical evaluations were based on an ANOVA test $(p=0.05)$ using the Microcal Origin 5.0 software program.

\section{RESULTS AND DISCUSSION}

Physicochemical parameters of honey: The results of moisture, free acidity, $\mathrm{pH}$ and total phenolic content of honey samples are presented in Table 2. Honey samples from the middle-east region of Argentina arising from the Buenos Aires province correspond, usually, to lightcolored honey regardless of their mixed or monofloral origin (Iurlina et al., 2009). The color of the honey samples ranged from water white to clear amber and the average value according to Pfund method was $28.36 \pm 18.11 \mathrm{~mm}$ (Table 1). The province of Buenos Aires is situated in the zone called 'the wet Pampa' that is an extended plain tempered region with rain levels between 500 and $1000 \mathrm{~mm} /$ year. Clover, lotus, eucalypts, sunflower and thistle are part of the vegetation of apicultural interest (Cabrera, 1976). Similar results of $\mathrm{pH}$, free acidity and humidity were obtained by Malacalza et al. (2005) and Acquarone et al. (2007) who studied honey coming from Buenos Aires province. Free acidity presented significant differences between honey samples, $\mathrm{HC} 1, \mathrm{HC} 2$ and HC3 had the highest values, around 29.87 milliequivalents of $\mathrm{NaOH} / \mathrm{kg}$ of honey, meanwhile, $\mathrm{HC} 4$ and HC5 presented the lowest values, around 16.97 milliequivalents of $\mathrm{NaOH} / \mathrm{kg}$ of honey. The $\mathrm{pH}$ and moisture values showed no significant differences $(\mathrm{p}>0.05)$.

In our study, the total phenolic content of the samples ranged from 7.36 to $14.42 \mathrm{mg} \mathrm{GAE} / 100 \mathrm{~g}$. Popova et al. (2007) found a correlation between the concentration of total phenolic in the propolis and its antimicrobial properties. In addition, the phenolic content of honey samples has also been associated with antimicrobial activity (Küçük et al., 2007).

HPLC analysis of quercetin, myricetin and luteolin in honey samples: Table 3 shows average values of quercetin, myricetin and luteolin of the five honey samples. The three flavonoids were present in all honey samples with the exception of luteolin in sample HC2. Quercetin was the main flavonoid found in the samples studied. Samples HC1, HC3 and HC4 had the highest values; between 1410 and 1930 $\mu \mathrm{g} / 100 \mathrm{~g}$ of honey. On the other hand, myricetin values 
Table 3: Quercetin, myricetin and luteolin content of honey samples Flavonoids $(\mu \mathrm{g} / 100 \mathrm{~g}$ of honey)

\begin{tabular}{llll} 
& & & \\
Honey sample & Quercetin & Myricetin & Luteolin \\
\hline HC1 & $1840 \pm 14.38^{\mathrm{c}}$ & $210 \pm 16.99^{\mathrm{d}}$ & $30 \pm 4.11^{\mathrm{b}}$ \\
HC2 & $220 \pm 10^{\mathrm{a}}$ & $6.6 \pm 0.29^{\mathrm{a}}$ & ND \\
HC3 & $1820 \pm 4.49^{\mathrm{c}}$ & $24 \pm 3.56^{\mathrm{b}}$ & $19 \pm 1.25^{\mathrm{a}}$ \\
HC4 & $1930 \pm 10.49^{\mathrm{c}}$ & $18.3 \pm 1.43^{\mathrm{b}}$ & $45 \pm 3.86^{\mathrm{c}}$ \\
HC5 & $1410 \pm 11.86^{\mathrm{b}}$ & $96 \pm 6.02^{\mathrm{c}}$ & $17 \pm 3.39^{\mathrm{a}}$ \\
\hline
\end{tabular}

ND: Not detected; Values are expressed as arithmetic mean \pm standard deviation $(\mathrm{n}=3)$; ${ }^{\mathrm{a}, \mathrm{b}, \mathrm{c}, \mathrm{d}}$ : The subscripts letters along the column indicate significant difference $(\mathrm{p}<0.05)$
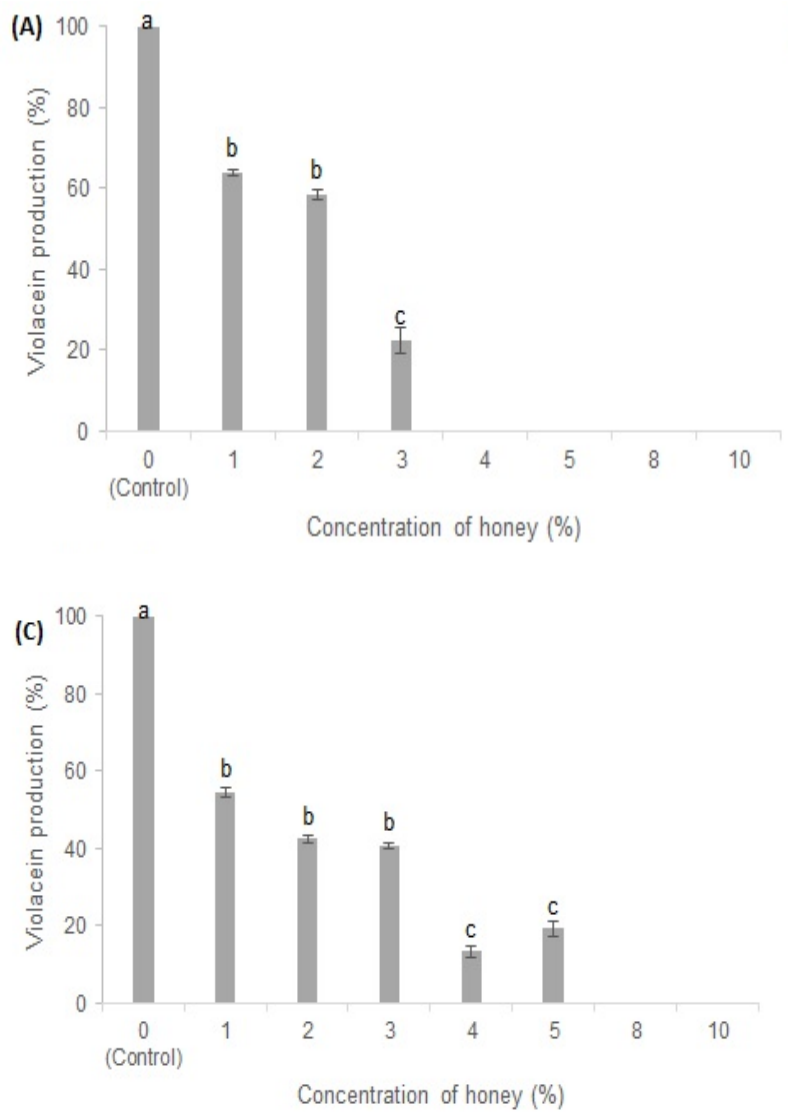

varied between 6.6 and $210 \mu \mathrm{g} / 100 \mathrm{~g}$ of honey with significant differences $(\mathrm{p}<0.05)$ and luteolin content varied between 17 and $45 \mu \mathrm{g} / 100 \mathrm{~g}$ of honey with significant differences $(\mathrm{p}<0.05)$. In accordance with the floral origin of our samples, Martos et al. (2000) studied European Eucalyptus honey and found a common and characteristic flavonoid composition, where myricetin, tricetin, quercetin, luteolin and kaempferol are quite constant in their concentration and relative amounts.
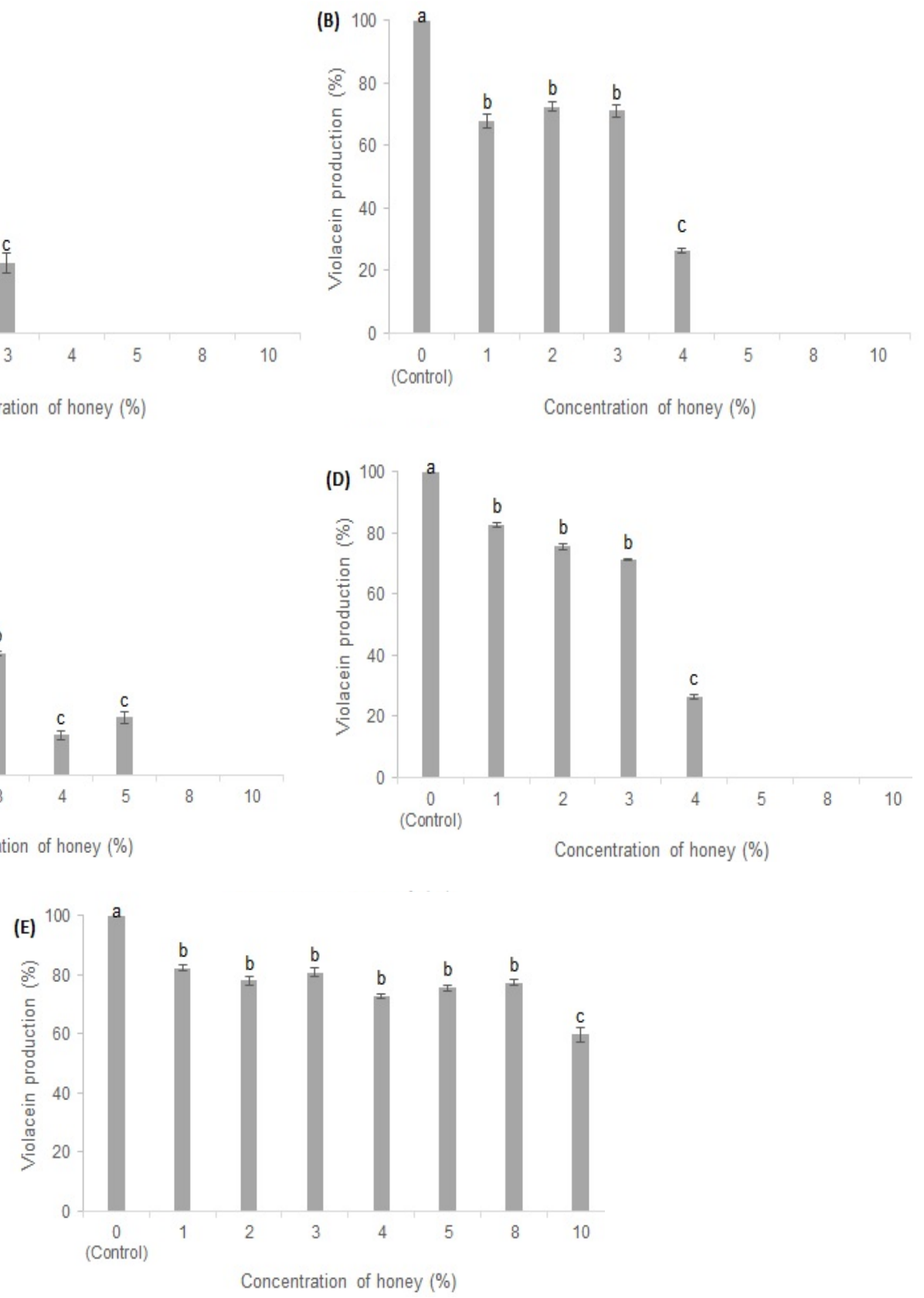

Fig. 1: Inhibition of violacein production by honey using Chromobacterium violaceum as indicator strain. HC1 (A), HC2 (B), HC3 (C), HC4 (D) and HC5 (E). The absorbance of measured violacein was transformed in percentage with the untreated (control) set as $100 \%$. Data are represented as mean \pm standard deviation, $n=3$. Different letters in the columns are significantly different $(\mathrm{p}<0.05)$ 
Anti-QS activity of honey: The agar-well diffusion assay was performed with $C$. violaceum to determine the pigment inhibition of honey samples. Different concentrations were used to obtain a qualitative screening of the sensibility of the bacteria. No differences were observed in the production of violacein between honey samples when were tested at concentrations below $10 \%(\mathrm{w} / \mathrm{v})$. Concentrations higher than $10 \%(\mathrm{w} / \mathrm{v})$ of honey were needed to produce complete inhibition in C. violaceum growth. Therefore, the flask-incubation assay to quantify the inhibition of violacein production by honey was carried out using concentrations from $1 \%$ to $10 \%(\mathrm{w} / \mathrm{v})$. Figure 1 shows the percentage of violacein production at different concentrations of honey. Honey samples $\mathrm{HC} 1$ and $\mathrm{HC} 3$ showed the highest anti-QS activity (Fig. 1A and 1C), while $\mathrm{HC} 2$ and HC4 showed the lowest inhibitory activity (Fig. 1B and D) and HC5 did not show anti-QS activity at the concentrations assayed. Truchado et al. (2009) found that unifloral honeys produced a significant drop in violacein production, even at the lowest tested concentration $(0.1 \mathrm{~g} / \mathrm{mL})$ indicating its anti-QS activity. The inhibition produced in our studies was considerably higher as previously reported by Truchado et al. (2009). Honey $\mathrm{HCl}$ at $3 \%(\mathrm{w} / \mathrm{v})$ reduced violacein production by more than $70 \%$ (Fig. $1 \mathrm{~A})$ and $\mathrm{HC} 3$ honey at $2 \%(\mathrm{w} / \mathrm{v})$ reduced violacein production more than $50 \%$ (Fig. 1C). Considering the results obtained, the Minimum Quorum Sensing Inhibitory Concentration (MQSIC) of the honey samples was estimated (Table 4). The MQSIC is designated as the effective concentration of bioactive at witch $50 \%$ of the QS activity was reduced. Estimation was developed by linear regression after the logarithmic transformation of the violacein production data for different concentration of each honey (data shown in Fig. 1). The MQSIC of honey samples was lower to the concentration at which bacterial growth $(C$. violaceum $)$ showed significant differences compared with control cells. As it was explained before, $\mathrm{HC} 1$ and $\mathrm{HC} 3$ honey samples were those with the lowest MQSIC (Table 4) demonstrating their high anti-QS capacity at low concentration, $3.16 \%$ to $\mathrm{HC} 1$ and $3.23 \%$ to $\mathrm{HC} 3$. Samples HC1 and HC3 were characterized by high content of quercetin $1840 \mu \mathrm{g} / 100 \mathrm{~g}$ and $1820 \mu \mathrm{g} / 100 \mathrm{~g}$ of honey, respectively. In addition, free acidity of $\mathrm{HCl}$ and $\mathrm{HC} 3$ showed values above 24 milliequivalents of $\mathrm{NaOH} / \mathrm{kg}$ of honey. On the other hand, HC2 presented low content of quercetin $(220 \mu \mathrm{g} / 100 \mathrm{~g}$ of honey) and high acidity (around 32 milliequivalents of $\mathrm{NaOH} / \mathrm{kg}$ of honey). Opposite that $\mathrm{HC} 4$ presented the highest content of quercetin $(1940 \mu \mathrm{g} / 100 \mathrm{~g}$ of honey) but the lowest value of free acidity (16.53 milliequivalents of $\mathrm{NaOH} / \mathrm{kg}$ of honey). We hypothesized that the antiquorum sensing activity observed is related to the synergistic effect of quercetin and free acidity. Quercetin is a naturally occurring flavonoid which belongs to the group of phenolic compounds. The profiles of phenolic compounds in honey differ according to the floral origins (Campos et al., 1990).
Table 4: Minimum quorum sensing inhibitory concentrations (MQSICs) of honey samples against Chromobacterium violaceum

\begin{tabular}{lll}
\hline Honey sample & MQSIC $(\%)$ & $\mathrm{R}^{2}$ \\
\hline $\mathrm{HC} 1$ & $3.16(3.08-3.24)$ & 0.84 \\
$\mathrm{HC} 2$ & $3.8(3.72-3.88)$ & 0.82 \\
$\mathrm{HC} 3$ & $3.23(3.15-3.31)$ & 0.87 \\
$\mathrm{HC} 4$ & $4.16(4.08-4.24)$ & 0.91 \\
$\mathrm{HC} 5$ & $11.9(11.82-11.98)$ & 0.70 \\
\hline MQSIC are presented as the mean value (95\% confidence interval) \\
and regression coefficient is included
\end{tabular}

Previous studies have linked the anti-QS activity of honey and propolis to flavonoids (Truchado et al., 2009; Alvarez et al., 2012). In addition, Borges et al. (2014) evaluated the quorum quenching activity of isolated phenolic compounds in the concentration of $1000 \mu \mathrm{g} / \mathrm{mL}$ and found that gallic acid, ferulic acid and caffeic acid reduced violacein production more than $59 \%$.

Antimicrobial activity of honey: To evaluate whether the inhibition of violacein production is due to the reduction in the microbial growth or the AHL inhibition, the antimicrobial activity of honey was analyzed using C. violaceum as indicator (Fig. 2). None of the tested honey samples showed antimicrobial activity when applied at MQSIC (data not shown); although this concentration was enough to significantly reduce the violacein production to $50 \%$ (Fig. 1). In the case of samples $\mathrm{HC} 2$ and $\mathrm{HC} 4$, the concentration at which there was a significant $(\mathrm{p}<0.05)$ antimicrobial effect on C. violaceum was at $4 \%$ and $5 \%(\mathrm{w} / \mathrm{v})$ of honey, respectively (Fig. 3), while $\mathrm{HC} 1, \mathrm{HC} 3$ and $\mathrm{HC} 5$ did not show antimicrobial activity when applied at $10 \%(\mathrm{w} / \mathrm{v})$ of honey. Possibly, honey concentrations higher than those tested are needed to produce a significant reduction in $C$. violaceum growth.

Quercetin, myricetin and luteolin activity at pH 5.8: As it was mentioned before, a probable relation exists between the anti-QS activity, concentration of quercetin and the acidity. Therefore, the inhibition of violacein production by $C$. violaceum, due to quercetin, myricetin and luteolin in an acidified medium was also evaluated. The assays were performed employing the flavonoid solutions at $\mathrm{pH}$ 5.8. According to Movileanu et al. (2000), the bioactivity of flavonoids like quercetin is $\mathrm{pH}$ dependent and its polarity can change depending on the $\mathrm{pH}$. On the other hand, Cushnie and Lamb (2005) proposed that flavonoids have an antibacterial effect depending on the number and distribution of hydroxyl groups in the molecule. Nevertheless, there is no information about the effect of flavonoids on the antiQS system when the medium is acidified. Figure 3 shows the percentage of violacein production at increasing concentrations of the bioactive agents at $\mathrm{pH}$ 5.8 and 6.7 as control. Quercetin showed the highest anti-QS activity at $\mathrm{pH} 5.8$ (Fig. 3A), while myricetin and luteolin showed the lowest inhibitory activity (Fig. $3 \mathrm{~B}$ and $3 \mathrm{C}$ ). Compared with control ( $\mathrm{pH}$ 6.7), quercetin at $22 \mu \mathrm{g} / 100 \mathrm{~mL}$ produced a significant drop in 


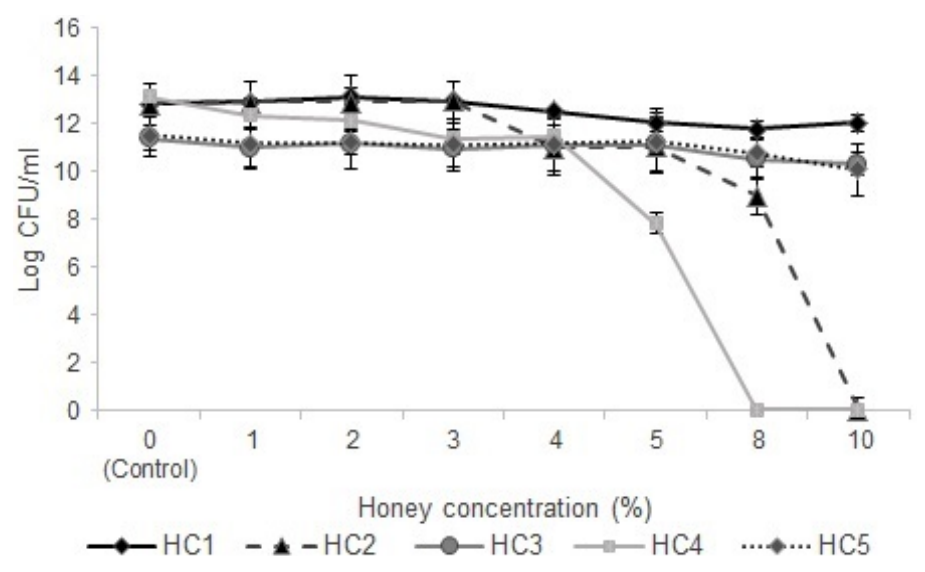

Fig. 2: Effect of increasing concentration of honey on the growth of Chromobacterium violaceum. Error bars represent standard deviation of three replicates
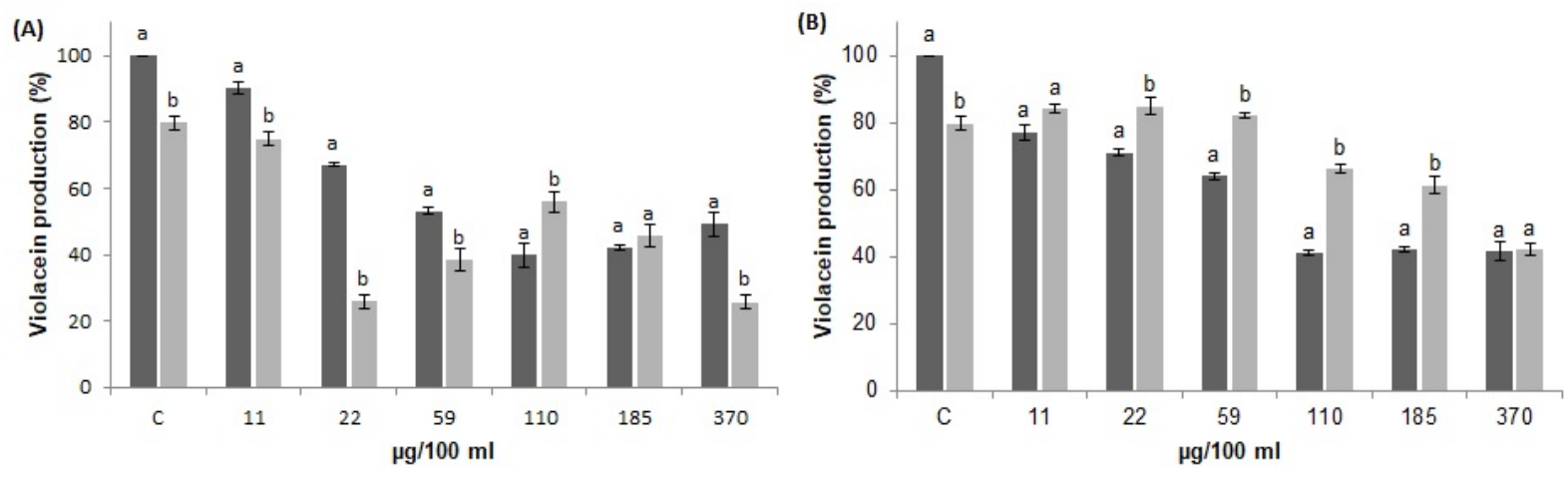

$$
\text { 口 } 6.7 \quad \square \mathrm{pH} 5.8
$$



Fig. 3: Inhibition of violacein production at increasing concentrations of main flavonoids in acidified and non-acidified LB culture medium. Dark grey bars correspond to $\mathrm{pH} 6.7$ and light grey bars to $\mathrm{pH}$ 5.8.; Quercetin (A) Myricetin (B) and Luteolin $(\mathrm{C})$. The absorbance of measured violacein was transformed in percentage with the untreated (control) set as $100 \%$

violacein production, more than $50 \%$ of the violacein synthesis was inhibited indicating strong anti-QS activity in an acidic medium. Studies carried out by Movileanu et al. (2000), demonstrated that the intercalation of quercetin molecules between the acyl chains of phospholipids of the lipid bilayer is significant at lower $\mathrm{pH}$ when the quercetin molecules are not dissociated. In this condition, molecules are completely liposoluble and they insert deeper into the hydrophobic core than at neutral or alkaline $\mathrm{pH}$. Meanwhile, the inhibition of violacein by myricetin was significant at $110 \mu \mathrm{g} / 100 \mathrm{~mL}$ when $\mathrm{pH}$ was 6.7 (control), suggesting that the anti-QS activity of this flavonoid was not modified at $\mathrm{pH}$ 5.8. On the other 
hand, the inhibition of violacein by luteolin was the same at pH 5.8 and 6.7. Considering the results of the anti-QS activity of the honeys tested, the free acidity of honey would modify the activity of quercetin present in honey. Therefore, the anti-QS activity of samples $\mathrm{HC1}$ and $\mathrm{HC} 3$ was attributed to the combination of high content of quercetin and high acidity. On the other hand, the lowest anti-QS activity of sample HC2 could be attributed to the low concentration of quercetin (220 $\mu \mathrm{g} / 100 \mathrm{~g}$ of honey) although the acidity of $\mathrm{HC} 2$ was high (33.06 milliequivalents of $\mathrm{NaOH} / \mathrm{Kg}$ of honey). The same effect was observed with honey $\mathrm{HC} 4$ which had a high concentration of quercetin $(1930 \mu \mathrm{g} / 100 \mathrm{~g}$ of honey) but presented low value of free acidity (16.53 milliequivalents of $\mathrm{NaOH} / \mathrm{kg}$ of honey). Finally, the anti-QS effect of sample HC5 was not significant $(p>0.05)$ because it was needed a concentration of $11.9 \%(\mathrm{w} / \mathrm{v})$ of honey in order to reach $50 \%$ of inhibition of violacein production (Table 4).

\section{CONCLUSION}

In the present study, we determine a correlation between honey free acidity, quercetin concentration and the anti-QS activity. Quercetin was the dominant flavonoid in honey samples and it was considered the main cause of QS inhibition coming from honey. However, an acidity threshold value was necessary to potentiate the activity of this flavonoid. A free acidity value of 24 milliequivalents of $\mathrm{NaOH} / \mathrm{Kg}$ of honey can modify the polarity of some phenolic compounds and thus determine their ability to adhere to biological membranes contributing to the anti-QS capacity. Therefore, the control of bacterial communication using honey typified on their phenolic content could be favored in an acidic medium.

\section{ACKNOWLEDGMENT}

We gratefully acknowledge the financial support of the Universidad Nacional of Mar del Plata (15/E754 EXA 803/16).

\section{REFERENCES}

Acquarone, C., P. Buera and B. Elizalde, 2007. Pattern of $\mathrm{pH}$ and electrical conductivity upon honey dilution as a complementary tool for discriminating geographical origin of honeys. Food Chem., 101(2): 695-703.

Alvarez, M.V., M.R. Moreira and A. Ponce, 2012. Antiquorum sensing and antimicrobial activity of natural agents with potential use in food. J. Food Saf., 32(3): 379-387.

Bassler, B.L., 1999. How bacteria talk to each other: Regulation of gene expression by quorum sensing. Curr. Opin. Microbiol., 2(6): 582-587.
Bath, P.K. and N. Singh, 1999. A comparison between Helianthus annuus and Eucalyptus lanceolatus honey. Food Chem., 67(4): 389-397.

Bianchi, E.M., 1984. Capitulo III: Determinación del Contenido de Humedad. Capítulo VI: Determinación de Acidez. In: Determinación de la Calidad de Miel. (Ed.), CEDIA-Universidad Nacional de Santiago del Estero; Santiago del Estero, Rep. Argentina, pp: 17-25.

Borges, A., S. Serra, A. Cristina Abreu, M.J. Saavedra, A. Salgado and M. Simões, 2014. Evaluation of the effects of selected phytochemicals on quorum sensing inhibition and in vitro cytotoxicity. Biofouling, 30(2): 183-195.

Brackman, G., U. Hillaert, S. Van Calenbergh, H.J. Nelis and T. Coenye, 2009. Use of quorum sensing inhibitors to interfere with biofilm formation and development in Burkholderia multivorans and Burkholderia cenocepacia. Res Microbiol., 160(2): 144-151.

Cabrera, A., 1976. Regiones Fitogeográficas Argentinas. In: Enciclopedia Argentina de Agricultura y Jardinería. Segunda Edición, Buenos Aires, Argentina, Tomo II. Fascículo I: ACME, pp: 85.

Campos, M.D.G.R., S. Sabatier, M.J. Amiot and S. Aubert, 1990. Characterization of flavonoids in three hive products: Bee pollen, propolis and honey. Planta Med., 56: 580-581.

Choo, J.H., Y. Rukayadi and J.K. Hwang, 2006. Inhibition of bacterial quorum sensing by vanilla extract. Lett. Appl. Microbiol., 42(6): 637-641.

Cushnie, T.P. and A.J. Lamb, 2005. Antimicrobial activity of flavonoids. Int. J. Antimicrob. Agents, 26(5): 343-356.

Fangio, M.F., M.O. Iurlina and R. Fritz, 2010. Characterisation of Argentinean honeys and evaluation of its inhibitory action on Escherichia coli growth. Int. J. Food Sci. Technol., 45(3): 520529.

Ferreira, I.C.F.R., E. Aires, J.C.M. Barreira and L.M. Estevinho, 2009. Antioxidant activity of Portuguese honey samples: Different contributions of the entire honey and phenolic extract. Food Chem., 114(04): 1438-1443.

Gram, L., L. Ravn, M. Rasch, J.B. Bruhn, A.B. Christensen and M. Givskov, 2002. Food spoilage-Interactions between food spoilage bacteria. Int. J. Food Microbiol., 78(1-2): 79-97.

Isla, M.I., A. Craig, R. Ordonez, C. Zampini, J. Sayago et al., 2011. Physico chemical and bioactive properties of honeys from Northwestern Argentina. LWT-Food Sci. Technol., 44(9): 1922-1930.

Iurlina, M.O. and R. Fritz, 2005. Characterization of microorganisms in Argentinean honeys from different sources. Int. J. Food Microbiol., 105(3): 297-304. 
Iurlina, M.O., A.I. Saiz, R. Fritz and G.D. Manrique, 2009. Major flavonoids of Argentinean honeys. Optimisation of the extraction method and analysis of their content in relationship to the geographical source of honeys. Food Chem., 115(3): 1141-1149.

Küçük, M., S. Kolaylı, Ş. Karaoğlu, E. Ulusoy, C. Baltacı and F. Candan, 2007. Biological activities and chemical composition of three honeys of different types from Anatolia. Food Chem., 100(2): 526-534.

Malacalza, N.H., M.A. Caccavari, G. Fagúndez and C.E. Lupano, 2005. Unifloral honeys of the province of Buenos Aires, Argentine. J. Sci. Food Agr., 85(8): 1389-1396.

Martos, I., F. Ferreres, L. Yao, B. D’Arcy, N. Caffin and F.A. Tomás-Barberán, 2000. Flavonoids in monospecific Eucalyptus honeys from Australia. J. Agr. Food Chem., 48(10): 4744-4748.

Mavric, E., S. Wittmann, G. Barth and T. Henle, 2008. Identification and quantification of methylglyoxal as the dominant antibacterial constituent of Manuka (Leptospermum scoparium) honeys from New Zealand. Mol. Nutr. Food Res., 52(4): 483489.

Movileanu, L., I. Neagoe and M.L. Flonta, 2000. Interaction of the antioxidant flavonoid quercetin with planar lipid bilayers. Int. J. Pharm., 205(1-2): 135-146.

Popova, M.P., V.S. Bankova, S. Bogdanov, I. Tsvetkova, C. Naydenski et al., 2007. Chemical characteristics of poplar type propolis of different geographic origin. Apidologie, 38(3): 306-311.

Singleton, V.L., R. Orthofer and R.M. LamuelaRaventós, 1999. Analysis of total phenols and other oxidation substrates and antioxidants by means of Folin-Ciocalteu reagent. Method. Enzymol., 299: 152-178.

Truchado, P., F. López-Gálvez, M.I. Gil, F.A. TomásBarberán and A. Allende, 2009. Quorum sensing inhibitory and antimicrobial activities of honeys and the relationship with individual phenolics. Food Chem., 115(4): 1337-1344.

Vandeputte, O.M., M. Kiendrebeogo, T. Rasamiravaka, C. Stévigny, P. Duez et al., 2011. The flavanone naringenin reduces the production of quorum sensing-controlled virulence factors in Pseudomonas aeruginosa PAO1. Microbiology, 157: 2120-2132.

Vasavi, H.S., A.B. Arun and P.D. Rekha, 2014. Antiquorum sensing activity of flavonoid-rich fraction from Centella asiatica L. against Pseudomonas aeruginosa PAO1. J. Microbiol. Immunol. Infect., 49(01): 8-15.

Vattem, D.A., K. Mihalik, S.H. Crixell and R.J. McLean, 2007. Dietary phytochemicals as quorum sensing inhibitors. Fitoterapia, 78(4): 302-310.

Vikram, A., G.K. Jayaprakasha, P.R. Jesudhasan, S.D. Pillai and B.S. Patil, 2010. Suppression of bacterial cell-cell signalling, biofilm formation and type III secretion system by citrus flavonoids. J. Appl. Microbiol., 109(2): 515-527. 